\title{
CXCL8 induces epithelial-mesenchymal transition in colon cancer cells via the $\mathrm{PI3K} / \mathrm{Akt} / \mathrm{NF}-\kappa \mathrm{B}$ signaling pathway
}

\author{
TAO SHEN $^{1 *}$, ZHIBIN YANG $^{1 *}$, XIANSHUO CHENG ${ }^{1}$, YOUCHUAN XIAO $^{2}$, KUN YU $^{1}$, \\ $\mathrm{XINYI} \mathrm{CAI}^{1}, \mathrm{CUIFENG} \mathrm{XIA}^{1}$ and YUNFENG LI ${ }^{1}$ \\ ${ }^{1}$ Department of Colorectal Surgery, The Third Affiliated Hospital of Kunming Medical University, Kunming, Yunnan 650118; \\ ${ }^{2}$ Department of Oncology, Qujing First People's Hospital of Yunnan Province, Qujing, Yunnan 655000, P.R. China
}

Received June 5, 2016; Accepted November 15, 2016

DOI: $10.3892 /$ or.2017.5453

\begin{abstract}
The aim of the present study was to investigate the role of chemokine (C-X-C motif) ligand 8 (CXCL8) in the proliferation, invasiveness and metastasis of colon cancer and its role in the induction of epithelial-mesenchymal transition (EMT) via activation of the phosphatidylinositol 3-kinase $(\mathrm{PI} 3 \mathrm{~K}) /$ protein kinase $\mathrm{B}(\mathrm{Akt}) /$ nuclear factor- $\kappa \mathrm{B}(\mathrm{NF}-\kappa \mathrm{B})$ pathway. The plasmid vector containing CXCL8 cDNA was transfected into LoVo cells using Lipofectamine 2000 reagent. Real-time PCR and western blot analyses were performed to determine expression of CXCL8. MTT growth inhibition, scratch and Transwell invasion assays were conducted to assess cell proliferation, migration and invasiveness of the CXCL8-transfected LoVo cells. Western blot analyses were conducted to measure the levels of phosphorylation of protein in the PI3K/Akt/NF- $\kappa \mathrm{B}$ pathway in the CXCL8-transfected LoVo cells. Expression levels of CXCL8 mRNA and protein were significantly increased in the CXCL8-transfected LoVo cells compared with levels in the control and empty-vector cells $(\mathrm{P}<0.05)$. Overexpression of CXCL8 increased proliferation of the LoVo cells and significant differences in cell viability were observed $48 \mathrm{~h}$ after transfection $(\mathrm{P}<0.05)$ and remained significant at 72 and $96 \mathrm{~h}$. CXCL8-transfected LoVo cells had a significantly higher migration rate and doubled invasion. The CXCL8-transfected LoVo cells exhibited an EMT-like phenotype, compared with control and empty-vector cells, with decreased expression of E-cadherin accompanied by increased expression of $\mathrm{N}$-cadherin, vimentin and $\alpha$-SMA. Overexpression of CXCL8 activated the PI3K/Akt/NF- $\kappa \mathrm{B}$ pathway by promoting the phosphorylation of PI3K, Akt and
\end{abstract}

Correspondence to: Dr Yunfeng Li, Department of Colorectal Surgery, The Third Affiliated Hospital of Kunming Medical University, 519 Kunzhou Road, Kunming, Yunnan 650118, P.R. China

E-mail: liyunfeng@medmail.com.cn

*Contributed equally

Key words: CXCL8, PI3K/Akt/NF-кB, LoVo colon cancer cells, EMT
NF-кB. Subcutaneous tumors were generated by subcutaneous injection of LoVo parental cells or CXCL8-transfected LoVo cells in BALB/c nude mice. The tumor growth was more rapid in the CXCL8-transfected group than that noted in the parental cell group. In conclusion, overexpression of CXCL8 induced cell proliferation, migration and invasion of colon cancer LoVo cells. CXCL8 may act through induction of EMT via the PI3K/ $\mathrm{AKT} / \mathrm{NF}-\kappa \mathrm{B}$ signaling axis.

\section{Introduction}

Colon cancer is the third most commonly diagnosed cancer and the fourth leading cause of cancer-related deaths worldwide, accounting for over 1.2 million new cases and 608,700 deaths per year (1). Despite advances in diagnosis and treatment strategies, cancer metastasis contributes to the majority of cancer-related deaths in colon cancer (2). Cancer metastasis is a complex event that involves sequential, interlinked and selective steps. Increasing evidence indicates that epithelial-mesenchymal transition (EMT) plays a critical and intricate role in promoting tumor invasion and metastasis in epithelium-driven malignancies (3). In the event of EMT, epithelial cells undergo multiple biochemical changes that enable them to disrupt cell-cell adherence and acquire mesenchymal characteristics such as enhanced migratory capacity, invasiveness and elevated resistance to apoptosis.

Chemokine (C-X-C motif) ligand 8 (CXCL8 or interleukin 8 ) and its receptor $\mathrm{CXCR} 2$ are two important regulators of metastatic and advanced cancers. CXCL8 serves as an autocrine growth factor that promotes tumor growth, invasion, angiogenesis, metastases and resistance (4,5). CXCL8 expression in human colon cancer cells has been linked to metastatic potential and high invasiveness (6). Our previous study showed that CXCL8 and chemokine (C-C motif) ligand 20 (CCL20) synergistically promoted metastasis by coordinated induction of EMT in human colorectal cancer cell lines SW480 and Caco-2 and patients with co-expression of CXCL8 and CCL20 were more likely to develop liver metastasis and had a poor prognosis (7). However, the exact role of CXCL8 in the progressive growth of colon cancer remains unclear.

The aim of the present study was to investigate the role of CXCL8 in proliferation, invasiveness and metastasis of colon cancer. We hypothesized that overexpression of CXCL8 would 
induce EMT-like phenotype in LoVo colon cancer cells. Our results may provide a basis for the development of new therapies for colon cancer to decrease proliferation and migration.

\section{Materials and methods}

Cell culture and transfection. The LoVo cell line purchased from the Cell Bank, Chinese Academy of Science (Shanghai, China) was grown in RPMI-1640 medium, supplemented with $10 \%$ fetal bovine serum (FBS) and $1 \%$ penicillin/streptomycin in a $5 \% \mathrm{CO}_{2}$ incubator at $37^{\circ} \mathrm{C}$. The empty plasmid vector and the plasmid vector containing CXCL8 cDNA were purchased from GeneChem Co. (Shanghai, China) and were transfected into LoVo cells using Lipofectamine 2000 reagent and Opti-MEM ${ }^{\circledR}$ reduced serum media (Invitrogen, Carlsbad, CA, USA). Multiple clones were selected in the presence of $2 \mu \mathrm{g} / \mathrm{ml}$ puromycin.

Growth inhibition assay. The LoVo cell suspension was seeded into a 96-well plate (200 $\mu \mathrm{l} /$ well) with the adjusted concentration of $10 \times 10^{3}$ cells $/ \mathrm{ml}$, and immediately incubated overnight at $37^{\circ} \mathrm{C}$ with $5 \% \mathrm{CO}_{2}$ and saturated humidity. Groups included the control, empty vector and CXCL8 groups, in four duplications. Cell growth was assessed 12, 24, 48, 72 and $96 \mathrm{~h}$ later. Thirty microliters of $5 \mathrm{mg} / \mathrm{ml}$ MTT solution (Sigma, St. Louis, MO, USA) was added to each well, and the plate was further incubated for $4 \mathrm{~h}$. After this incubation period the bulk of the medium was removed using a Pasteur pipette fitted to a vacuum line, taking care to leave the formazan crystals behind. After removing the medium, dimethyl sulfoxide (DMSO) was supplemented with oscillation for $10 \mathrm{~min}$. The optical density (OD) was measured with a spectrophotometer (Olympus, Tokyo, Japan) at $450 \mathrm{~nm}$. The graph of the OD value of the cells was drawn with time as the $\mathrm{x}$-axis and absorbance as the $\mathrm{y}$-axis. Proliferation inhibition rate $=(1-$ OD of experiment group/OD of control group) $\mathrm{x} 100 \%$.

In vitro scratch assay. The LoVo cell suspension (control, empty vector and CXCL8-transfected groups) was seeded into a 6-well plate with the adjusted concentration of $4 \times 10^{5}$ cells $/ \mathrm{ml}$ and incubated overnight until cells reached $90 \%$ confluency. A $20-\mu 1$ pipette tip was used to create a scratch in the cell monolayer, and the plate was washed with phosphate-buffered saline (PBS). The cells were cultured in RPMI-1640 medium with 5\% FBS for $48 \mathrm{~h}$ before being observed under a microscope.

Cell invasion assay. Transwell invasion experiments were performed with 6-well Matrigel-coated chambers from BD Biosciences (Bedford, MA, USA). Briefly, the LoVo cells (control, empty vector and CXCL8 transfected groups) were allowed to grow to subconfluency and were serum-starved for $24 \mathrm{~h}$. After detachment with trypsin, the cells were washed with PBS, resuspended in serum-free medium and $6 \times 10^{4}$ cells were added to the upper chamber. Complete medium was added to the bottom wells of the chambers. After $24 \mathrm{~h}$, the cells that had not migrated were removed from the upper face of the filters using cotton swabs, and the cells that had migrated were fixed and stained with Giemsa stain. Images of three different x10 fields of view were captured from each membrane, and the number of migratory cells was counted using Fujifilm vl.1 software.
Real-time PCR. CXCL8-transfected clones were screened for CXCL8 expression. The RNA was collected with TRIzol ${ }^{\circledR}$ reagent (Roche, Mannheim, Germany) and the mRNA was reverse transcribed to cDNA using the PrimeScript RT reagent kit using the gDNA Eraser kit. Cycling conditions were $16^{\circ} \mathrm{C}$ for $30 \mathrm{~min}, 42^{\circ} \mathrm{C}$ for $30 \mathrm{~min}$ and $85^{\circ} \mathrm{C}$ for $10 \mathrm{~min}$. Approximately $3 \mu 1$ of total cDNA of each sample was amplified using real-time PCR in a final volume of $20 \mu 1$ of reaction mixture using the reagent kit purchased from Toyobo Co., Ltd. (Osaka, Japan). Cycling conditions consisted of denaturation at $95^{\circ} \mathrm{C}$ for $3 \mathrm{~min}, 40$ cycles at $95^{\circ} \mathrm{C}$ for $12 \mathrm{sec}$, and $62^{\circ} \mathrm{C}$ for $40 \mathrm{sec}$. CXCL8 mRNA expression level was determined by normalizing against GAPDH gene expression using the $2^{-\Delta \Delta \mathrm{Ct}}$ method.

Western blotting. Total cellular proteins ( $40 \mu \mathrm{g} / \mathrm{lane})$ prepared from the cultured cells were electrophoresed on sodium dodecyl sulfate-polyacrylamide gels and transferred to polyvinylidene difluoride membranes. Blots were blocked in 5\% skim milk and sequentially immunostained with primary and secondary horseradish peroxidase-conjugated antibodies at $4^{\circ} \mathrm{C}$ overnight and at room temperature for $1 \mathrm{~h}$, respectively. All antibodies were purchased from Cell Signaling Technology (Danvers, MA, USA). Immunoreactive proteins were visualized using an enhanced chemiluminescence detection system with exposure to X-ray film. The images were analyzed by Quantity One (Bio-Rad).

siRNA analysis. CXCL8 siRNAs (Santa Cruz Biotechnology, Inc., TX, USA) and Lipofectamine 2000 (Invitrogen) were separately diluted according to the manufacturer's protocol, mixed gently and incubated for $20 \mathrm{~min}$ at room temperature. The siRNA-Lipofectamine 2000 mixture was added to LoVo cells grown in 6-well plates to $80-90 \%$ confluence. The transfection reagent was replaced after $6 \mathrm{~h}$, and the cells were then treated with chemokines as described above. Scrambled control siRNA was used as the blank control.

In vivo studies in nude mice. BALB/c nude mice (Guangdong Medical Laboratory Animal Center, Guangdong, China) aged 6-8 weeks were housed in laminar flow cabinets under specific pathogen-free conditions in our animal laboratory at Kunming Medical University. All animal experiments were conducted with the approval from the Ethics Committee for Animal Research of the Kunming Medical University. Subcutaneous tumors were generated by subcutaneous injection of $1 \times 10^{6} / 0.2 \mathrm{ml}$ of LoVo parental cells or CXCL8-transfected LoVo cells in the right flank of the mice (three mice/group). The subcutaneous tumors were measured using Vernier gauge, and tumor volumes were calculated according to the equation: Tumor volume $=(\text { short diameter })^{2} \times$ (long diameter) $x$ 0.5. After one week of inoculation, the tumor volume was measured every four days up to 28 days. The growth rate of the tumors was compared between the parental cells and CXCL8-transfected cell groups.

Statistical analyses. All statistical analyses were performed using GraphPad Prism 5.0. Results are expressed as mean \pm SD. Between-group comparisons were performed using analyses of variance. All analyses were two-tailed and $\mathrm{P}<0.05$ was considered to indicate a statistically significant result. 

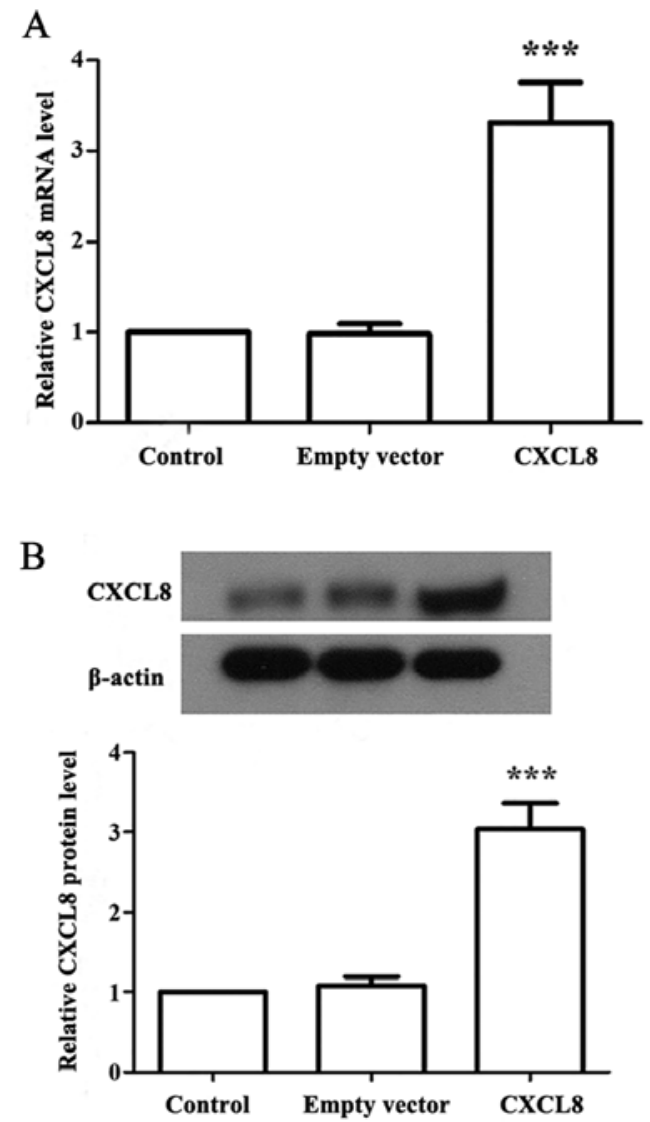

Figure 1. Stable transfection of CXCL8. (A) Expression of CXCL8 in control, empty-vector, and transfected LoVo cells by real-time PCR. (B) Expression of CXCL 8 by western blot analyses. ${ }^{* * *} \mathrm{P}<0.05$, compared with the control and empty-vector cells.

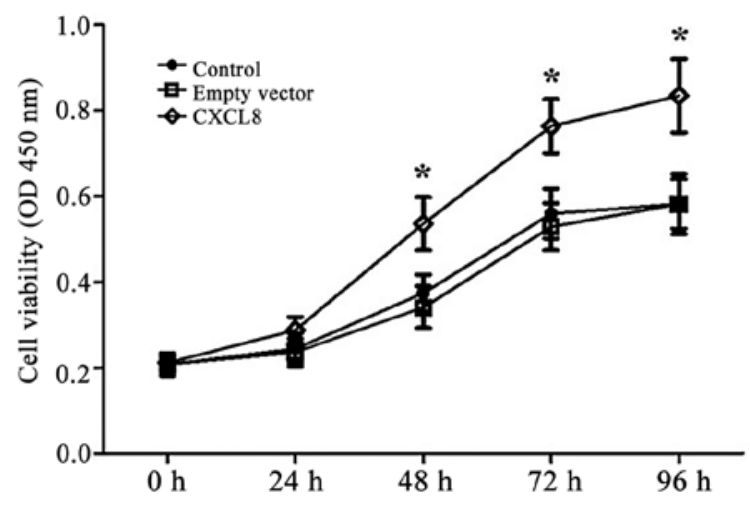

Figure 2. Overexpression of CXCL8 induced proliferation of the LoVo cells as determined by MTT growth inhibition assay. ${ }^{*} \mathrm{P}<0.05$.

\section{Results}

CXCL8 stable transfection. We quantified the expression of CXCL8 in the transfected LoVo cancer cell lines (Fig. 1). Realtime PCR showed that the CXCL8-transfected LoVo cells had significantly elevated CXCL8 mRNA expression when compared with that noted in the control and empty-vector cells $(\mathrm{P}<0.05)$. Western blotting showed a significantly increased level of CXCL8 protein in the CXCL8-transfected cells than the level noted in the control and empty-vector cells $(\mathrm{P}<0.05)$.
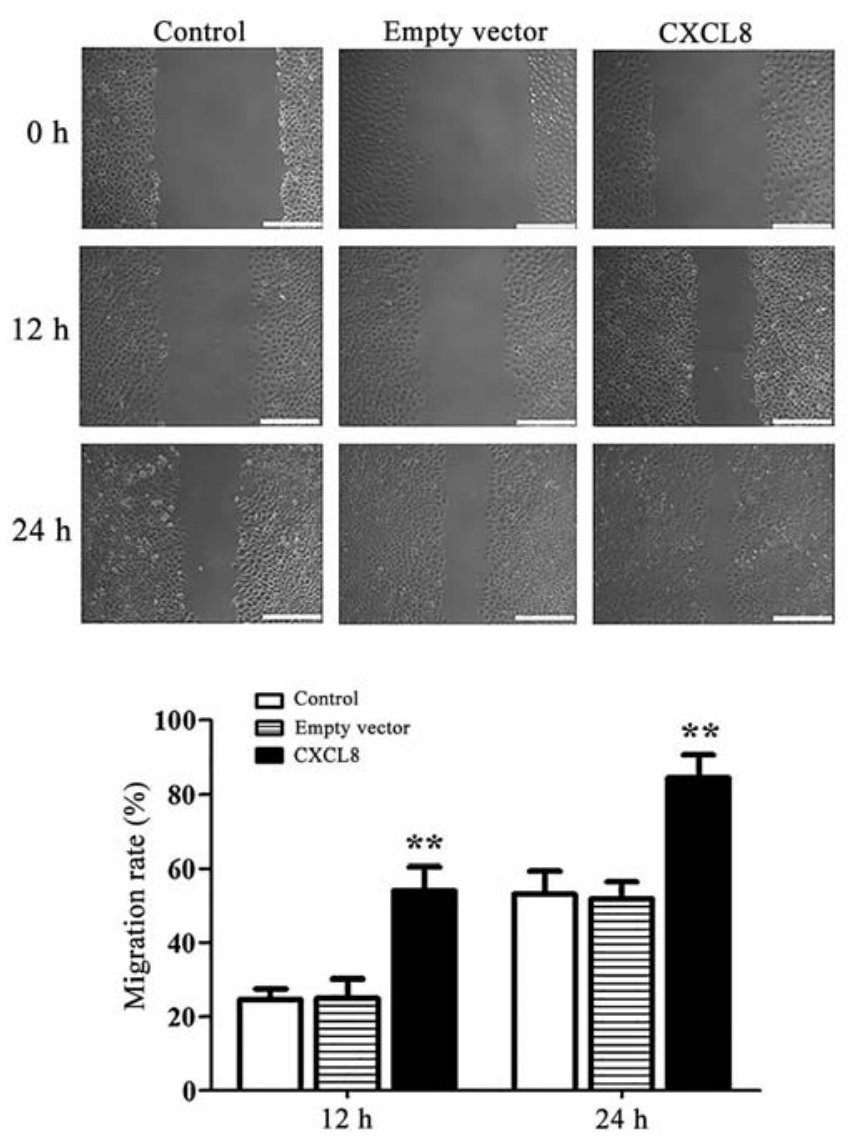

Figure 3. Overexpression of CXCL8 significantly promoted the migration of LoVo cells. ${ }^{* *} \mathrm{P}<0.01$, compared with the control and empty-vector cells.

CXCL8 increases proliferation of the LoVo cells. Fig. 2 shows the changes in OD values for the control, emptyvector and CXCL8-transfected LoVo cells using MTT assay. Overexpression of CXCL8 increased proliferation of the LoVo cells and its growth promotion effect was positively related to time. Significant differences in cell viability were observed $48 \mathrm{~h}$ after transfection $(\mathrm{P}<0.05)$ and remained significant at 72 and $96 \mathrm{~h}$.

CXCL8 increases migration and invasion of LoVo cells. The role of CXCL8 expression in the migratory potential of LoVo cells was investigated by scratch test. Fig. 3 shows that 12 and $24 \mathrm{~h}$ after transfection, the CXCL8-transfected cells had a significantly $(\mathrm{P}<0.01)$ higher migration rate than that observed in the control and empty-vector cells. Invasive potential was measured using Transwell invasion assay (Fig. 4). The CXCL8-transfected LoVo cells exhibited a 2 -fold increased invasion than that observed in the control and empty-vector cells $(\mathrm{P}<0.001)$.

CXCL8 induces EMT-like phenotype in LoVo cells. Western blotting showed that CXCL8-transfected LoVo cells exhibited EMT-like phenotype compared with control and empty-vector cells, with a decreased expression of E-cadherin accompanied by increased expression of $\mathrm{N}$-cadherin, vimentin and $\alpha$-SMA (Fig. 5). 

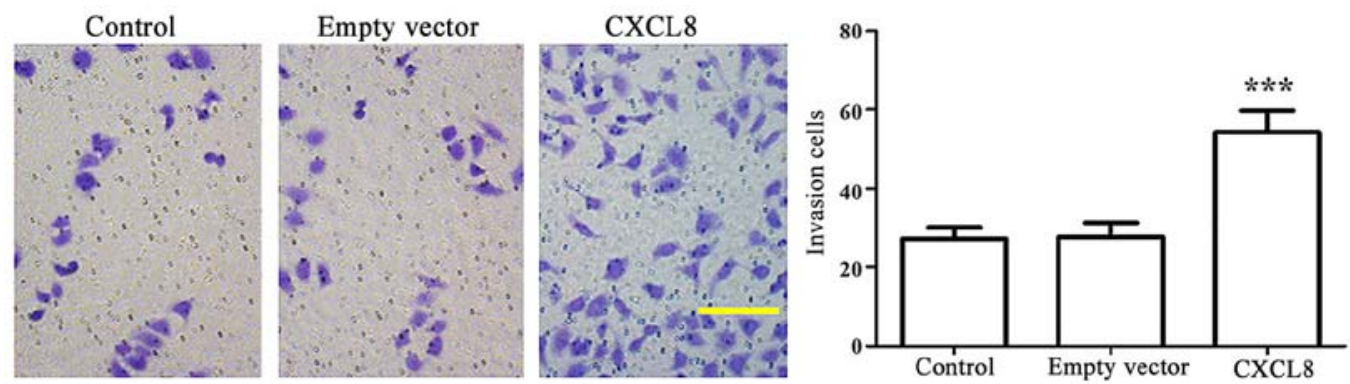

Figure 4. Overexpression of CXCL8 promoted invasion of the LoVo cells. ${ }^{* * *} \mathrm{P}<0.001$, compared with the control and empty-vector cells.

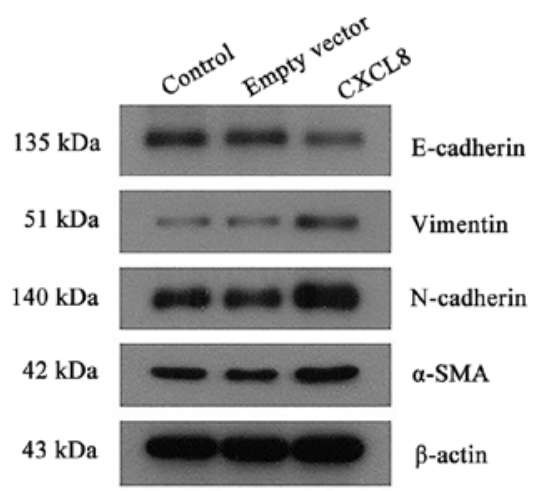

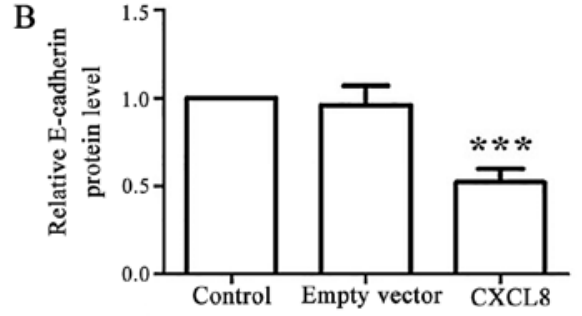

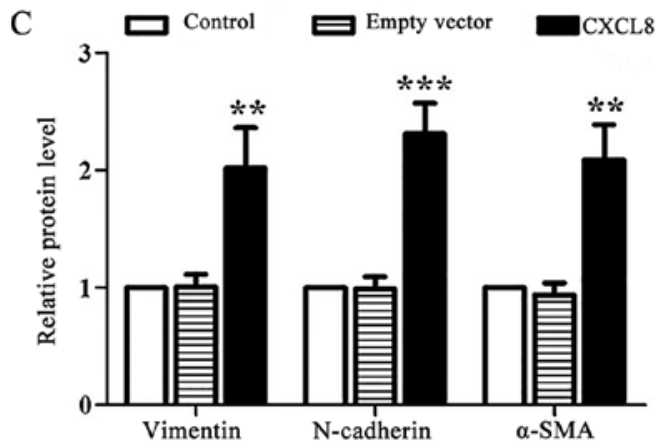

Figure 5. Overexpression of CXCL induced an epithelial-mesenchymal transition (EMT)-phenotype in the LoVo cells. (A) Expression of proteins related to EMT in the control, empty-vector, and transfected LoVo cells. (B) Quantification of E-cadherin. (C) Quantification of N-cadherin, vimentin and $\alpha$-SMA. ${ }^{* *} \mathrm{P}<0.01,{ }^{* * *} \mathrm{P}<0.001$, compared with the control and empty-vector cells.

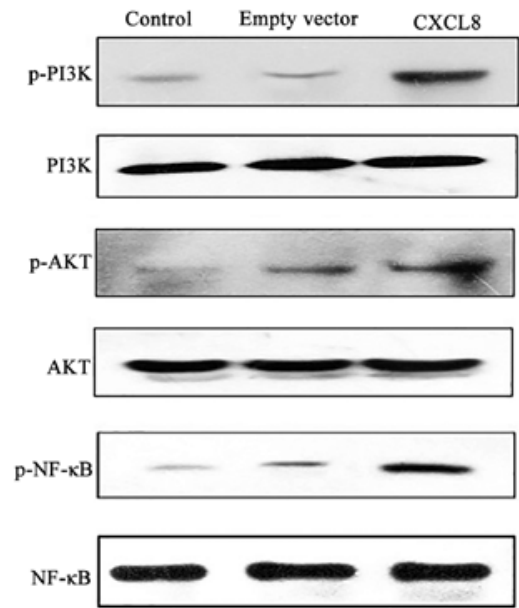

Figure 6. Overexpression of CXCL8 activated the PI3K/Akt/NF-kB signaling pathway in the LoVo cells.

CXCL8 activates the phosphatidylinositol 3-kinase (PI3K)/ protein kinase $B(P K B / A k t) / n u c l e a r$ factor $-\kappa B(N F-\kappa B)$ pathway. Compared with the control and empty-vector cells, overexpression of CXCL8 activated the PI3K/Akt/NF- $\mathrm{B}$ pathway by promoting phosphorylation of PI3K, Akt and NF- $\mathrm{BB}$ (Fig. 6). The efficacy of the silencing of CXCL8 on the PI3K/Akt/NF-kB pathway was determined by western blot analysis (Fig. 7). Compared to the cells transfected with non-specific siRNA, silencing of CXCL8 lowered the phosphorylation of PI3K and NF-kB. Phosphorylation of Akt appeared to be unaffected.

In vivo studies in nude mice. Subcutaneous tumors were generated by subcutaneous injection of LoVo parental cells or CXCL8-transfected LoVo cells in BALB/c nude mice. Fig. 8 shows the growth of tumor in the two groups. Tumor growth was more rapid in the CXCL8-transfected group than the growth observed in the parental cell group. At day 28, the tumor volume was significantly larger in the transfected cell group $(\mathrm{P}<0.05)$.

\section{Discussion}

In the present study, we examined the role of CXCL8 in the proliferation, migration and invasiveness in vitro in LoVo colon cancer cell line models and its ability to promote EMT. Our 


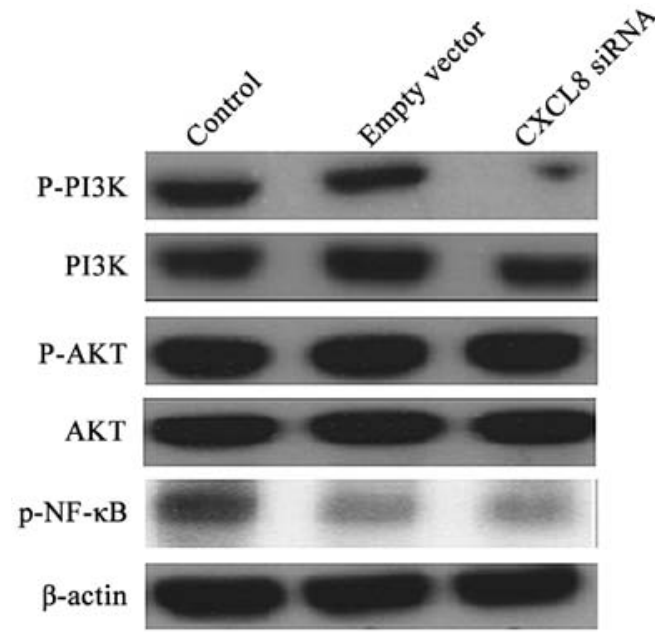

Figure 7. The effect of the silencing of CXCL8 on the PI3K/Akt/NF-kB pathway. Phosphorylation of PI3K and NF- $\mathrm{KB}$ was lower. Phosphorylation of Akt appeared to be unaffected.

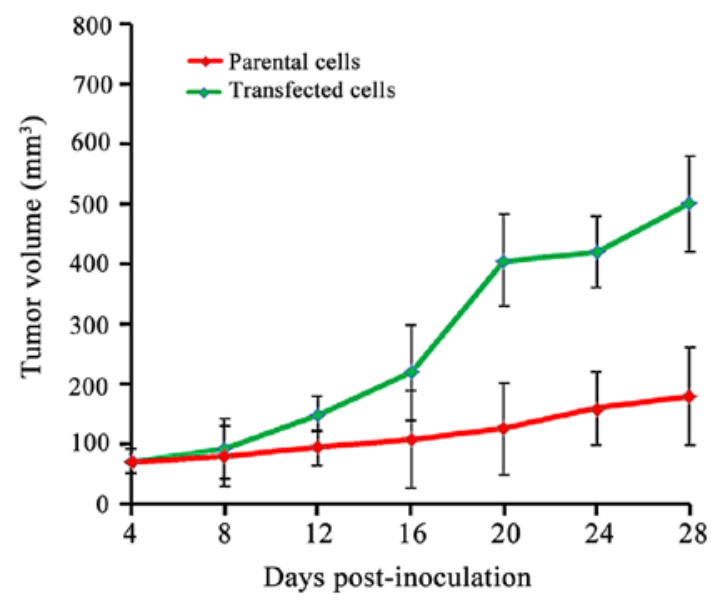

Figure 8. In vivo studies in nude mice to examine tumor growth in xenografts of colon cancer cells. Subcutaneous tumors were generated by subcutaneous injection of LoVo parental cells or CXCL8-transfected LoVo cells in BALB/C nude mice. The graph indicates the mean tumor growth rates $\pm \mathrm{SD}$ of three animals/experimental condition. At day 28 , the tumor volume was significantly larger in the transfected cell group $(\mathrm{P}<0.05)$.

results showed that CXCL8-transfected LoVo cells exhibited increased proliferation and enhanced migratory and invasive ability. In vivo studies in nude mice confirmed a faster tumor growth rate by the CXCL8-transfected LoVo cells. CXCL8 may act through induction of EMT via the PI3K/AKT/NF- $\mathrm{KB}$ signaling axis. Silencing of CXCL8 downregulated the phosphorylation of PI3K and NF- $\mathrm{kB}$.

Cancer metastasis is a complex process of multiple intricate and sequential steps. Over the past decade, there is accumulating evidence suggesting that EMT is a pathological process that plays a crucial role in cancer progression, particularly in cancer invasion, migration and metastasis (8). Recent studies have also shown that chemokines and their receptors act as key regulators of metastatic cancer, including colon cancer (9). They are involved in various neoplastic processes including growth signaling, acquisition of invasive properties, and emergence of a vascular network.
CXCL8 is a chemokine that stimulates the migratory capacity of a distinct set of leukocytes, and recent evidence suggests that it plays an important role in the metastasis of various types of cancers, including colon cancer $(10,11)$. Studies have shown significantly increased expression of CXCL8 in the tumor microenvironment and serum of patients with colon cancer $(4,10,12)$. Levels of CXCL8 were found to be correlated with tumor size, tumor grade, depth of infiltration and survival in colon cancer and they were decreased with successful treatment $(6,10,13,14)$. In the present study, stable CXCL8 transfection was successfully generated in colon cancer LoVo cell lines. Using MTT growth inhibition assay, we showed that constitutive expression of CXCL8 significantly stimulated the proliferation of LoVo cells. Furthermore, scratch and Transwell invasion assays showed that constitutive expression of CXCL8 significantly increased cell migration and invasion. In vivo study showed a faster tumor growth in the CXCL8-transfected cell group. Our results add to the evidence that expression of CXCL8 plays an important role in modulating cell proliferation, migration and invasion of colon cancer cells.

Activation of the PI3K/Akt signaling pathway is common in various types of cancers and it is involved in multiple events, including metastasis, invasion and immunologic escape (15-19). The PI3K/Akt signaling pathway has also been reported to be hyperactivated in several models of EMT $(20,21)$. A study by Malinowsky et al showed that activation of the PI3K/Akt pathway evidenced at the protein level was significantly correlated with prognosis in patients with stage II colon cancer (22). PI3K/Akt can be activated by a variety of chemokines via phosphorylation and consequently downregulates E-cadherin/ $\beta$-catenin complex expression, promoting cell migration and invasion in colon cancer cells $(21,23,24)$. Moreover, studies have shown that activation of the PI3K/ Akt pathway is also involved in activation of NF- $\mathrm{kB}$ via phosphorylation of inhibitory inhibitor of $\kappa \mathrm{B} \alpha(\mathrm{I} \kappa \mathrm{B} \alpha$ ) protein (25). This phosphorylation results in the dissociation of $\mathrm{I} \kappa \mathrm{B} \alpha$ from $\mathrm{NF}-\kappa \mathrm{B}$, allowing NF- $\kappa \mathrm{B}$ to freely migrate into the nucleus and activate the transcription of several genes involved in the suppression of cell death (26-28). NF- $\mathrm{KB}$ also regulates proliferation and invasiveness by regulating the expression of several genes involved in cell cycle machinery (29-31). Our results are concurrent with previous studies that demonstrated that overexpression of CXCL8 increased phosphorylation of the PI3K/Akt/NF- $\mathrm{KB}$ pathway, accompanied by an EMT phenotype evidence by a decreased expression of E-cadherin and an increased expression of $\mathrm{N}$-cadherin, vimentin and $\alpha$-SMA. These results suggest that CXCL8 induces EMT in colon cancer via activation of PI3K/Akt/NF- $\mathrm{kB}$ and CXCL8 has the potential as a therapeutic target for the treatment of colon cancer.

Findings from the present study need to be confirmed by future studies using human colon cancer tissue. In a previous study by Cheng et al, patients with co-expression of CCL20 and CXCL8 were more likely to develop liver metastases and had a poorer prognosis (7). Furthermore, although we performed knockdown experiment using siRNA of CXCL8 to investigate whether CXCL8 acts through the PI3K/Akt/NF- $\mathrm{KB}$ pathway, the knockdown experiment was not performed to confirm the effect of CXCL8 on colon cell proliferation, 
migration and invasion. A previous study by Ning et al found that siRNA-mediated knockdown of CXCL8 abrogated the increased cell migration and cell invasion noted in CXCL8transfected HCT116 cells (13).

In conclusion, the present study provides significant evidence that overexpression of CXCL8 promotes colon cancer cell proliferation, migration and invasion, and promotes tumor growth in vivo. It may act via activation of the PI3K/Akt/ $\mathrm{NF}-\kappa \mathrm{B}$ signaling pathway. Our results could serve as a basis for the development of novel anti-CXCL8-targeted therapies for colon cancer.

\section{Acknowledgements}

The present study was supported by the National Natural Science Foundation of China (Ref.: 81560472).

\section{References}

1. Jemal A, Bray F, Center MM, Ferlay J, Ward E and Forman D: Global cancer statistics. CA Cancer J Clin 61: 69-90, 2011.

2. Leporrier J, Maurel J, Chiche L, Bara S, Segol P and Launoy G: A population-based study of the incidence, management and prognosis of hepatic metastases from colorectal cancer. Br J Surg 93: 465-474, 2006.

3. Thiery JP: Epithelial-mesenchymal transitions in tumour progression. Nat Rev Cancer 2: 442-454, 2002.

4. Brat DJ, Bellail AC and Van Meir EG: The role of interleukin-8 and its receptors in gliomagenesis and tumoral angiogenesis. Neuro Oncol 7: 122-133, 2005

5. Yoshimura T, Matsushima K, Oppenheim JJ and Leonard EJ: Neutrophil chemotactic factor produced by lipopolysaccharide (LPS)-stimulated human blood mononuclear leukocytes: Partial characterization and separation from interleukin 1 (IL 1). J Immunol 175: 5569-5574, 2005.

6. Li A, Varney ML and Singh RK: Expression of interleukin 8 and its receptors in human colon carcinoma cells with different metastatic potentials. Clin Cancer Res 7: 3298-3304, 2001.

7. Cheng XS, Li YF, Tan J, Sun B, Xiao YC, Fang XB, Zhang XF, Li Q, Dong JH, Li M, et al: CCL20 and CXCL8 synergize to promote progression and poor survival outcome in patients with colorectal cancer by collaborative induction of the epithelial-mesenchymal transition. Cancer Lett 348: 77-87, 2014.

8. Leroy P and Mostov KE: Slug is required for cell survival during partial epithelial-mesenchymal transition of HGF-induced tubulogenesis. Mol Biol Cell 18: 1943-1952, 2007.

9. Tanaka T, Bai Z, Srinoulprasert Y, Yang BG, Hayasaka H and Miyasaka M: Chemokines in tumor progression and metastasis. Cancer Sci 96: 317-322, 2005.

10. Lee YS, Choi I, Ning Y, Kim NY, Khatchadourian V, Yang D, Chung HK, Choi D, LaBonte MJ, Ladner RD, et al: Interleukin-8 and its receptor CXCR2 in the tumour microenvironment promote colon cancer growth, progression and metastasis. Br J Cancer 106: 1833-1841, 2012

11. McClelland MR, Carskadon SL, Zhao L, White ES, Beer DG, Orringer MB, Pickens A, Chang AC and Arenberg DA: Diversity of the angiogenic phenotype in non-small cell lung cancer. Am J Respir Cell Mol Biol 36: 343-350, 2007.

12. Doll D, Keller L, Maak M, Boulesteix AL, Siewert JR, Holzmann B and Janssen KP: Differential expression of the chemokines GRO-2, GRO-3, and interleukin-8 in colon cancer and their impact on metastatic disease and survival. Int $\mathrm{J}$ Colorectal Dis 25: 573-581, 2010.

13. Ning Y, Manegold PC, Hong YK, Zhang W, Pohl A, Lurje G, Winder T, Yang D, LaBonte MJ, Wilson PM, et al: Interleukin-8 is associated with proliferation, migration, angiogenesis and chemosensitivity in vitro and in vivo in colon cancer cell line models. Int J Cancer 128: 2038-2049, 2011.
14. Rubie C, Frick VO, Pfeil S, Wagner M, Kollmar O, Kopp B, Graber S, Rau BM and Schilling MK: Correlation of IL-8 with induction, progression and metastatic potential of colorectal cancer. World J Gastroenterol 13: 4996-5002, 2007.

15. Dozmorov MG, Azzarello JT, Wren JD, Fung KM, Yang Q, Davis JS, Hurst RE, Culkin DJ, Penning TM and Lin HK: Elevated AKR1C3 expression promotes prostate cancer cell survival and prostate cell-mediated endothelial cell tube formation: Implications for prostate cancer progression. BMC Cancer 10: 672, 2010.

16. Jiao $M$ and Nan KJ: Activation of PI3 kinase/Akt/HIF-1 $\alpha$ pathway contributes to hypoxia-induced epithelial-mesenchymal transition and chemoresistance in hepatocellular carcinoma. Int J Oncol 40: 461-468, 2012.

17. Song L, Xiong H, Li J, Liao W, Wang L, Wu J and Li M: Sphingosine kinase-1 enhances resistance to apoptosis through activation of PI3K/Akt/NF- $\mathrm{KB}$ pathway in human non-small cell lung cancer. Clin Cancer Res 17: 1839-1849, 2011.

18. Vredeveld LC, Possik PA, Smit MA, Meissl K, Michaloglou C, Horlings HM, Ajouaou A, Kortman PC, Dankort D, McMahon M, et al: Abrogation of $\mathrm{BRAF}^{\mathrm{V} 600 \mathrm{E}}$-induced senescence by PI3K pathway activation contributes to melanomagenesis. Genes Dev 26: 1055-1069, 2012.

19. Wang D, Chen J, Chen H, Duan Z, Xu Q, Wei M, Wang L and Zhong $\mathrm{M}$ : Leptin regulates proliferation and apoptosis of colorectal carcinoma through PI3K/Akt/mTOR signalling pathway. J Biosci 37: 91-101, 2012.

20. Zhu G, Li X, Guo B, Ke Q, Dong M and Li F: PAK5-mediated E47 phosphorylation promotes epithelial-mesenchymal transition and metastasis of colon cancer. Oncogene 35: 1943-1954, 2016.

21. Wang L, Li CL, Wang L, Yu WB, Yin HP, Zhang GY, Zhang LF, $\mathrm{Li} \mathrm{S}$ and $\mathrm{Hu} \mathrm{SY}$ : Influence of CXCR4/SDF-1 axis on E-cadherin/ $\beta$-catenin complex expression in HT29 colon cancer cells. World J Gastroenterol 17: 625-632, 2011.

22. Malinowsky K, Nitsche U, Janssen KP, Bader FG, Späth C, Drecoll E, Keller G, Höfler H, Slotta-Huspenina J and Becker KF: Activation of the PI3K/AKT pathway correlates with prognosis in stage II colon cancer. Br J Cancer 110: 2081-2089, 2014.

23. Chen G, Chen SM, Wang X, Ding XF, Ding J and Meng LH: Inhibition of chemokine (CXC motif) ligand 12/chemokine (CXC motif) receptor 4 axis (CXCL12/CXCR4)-mediated cell migration by targeting mammalian target of rapamycin (mTOR) pathway in human gastric carcinoma cells. J Biol Chem 287: 12132-12141, 2012.

24. Huang CY, Fong YC, Lee CY, Chen MY, Tsai HC, Hsu HC and Tang CH: CCL5 increases lung cancer migration via PI3K, Akt and NF-kappaB pathways. Biochem Pharmacol 77: 794-803, 2009.

25. Dolcet X, Llobet D, Pallares $J$ and Matias-Guiu X: NF- $\kappa$ B in development and progression of human cancer. Virchows Arch 446: 475-482, 2005.

26. Jacobs MD and Harrison SC: Structure of an IkappaBalpha/ NF-kappaB complex. Cell 95: 749-758, 1998.

27. Kreuz S, Siegmund D, Scheurich $P$ and Wajant H: NF-kappaB inducers upregulate cFLIP, a cycloheximide-sensitive inhibitor of death receptor signaling. Mol Cell Biol 21: 3964-3973, 2001.

28. Micheau O, Lens S, Gaide O, Alevizopoulos K and Tschopp J: NF-kappaB signals induce the expression of c-FLIP. Mol Cell Biol 21: 5299-5305, 2001.

29. Guttridge DC, Albanese C, Reuther JY, Pestell RG and Baldwin AS Jr: NF-kappaB controls cell growth and differentiation through transcriptional regulation of cyclin D1. Mol Cell Biol 19: 5785-5799, 1999.

30. Hinz M, Krappmann D, Eichten A, Heder A, Scheidereit C and Strauss M: NF- $\kappa \mathrm{B}$ function in growth control: Regulation of cyclin D1 expression and $\mathrm{G}_{0} / \mathrm{G}_{1}$-to-S-phase transition. Mol Cell Biol 19: 2690-2698, 1999.

31. Hinz M, Löser P, Mathas S, Krappmann D, Dörken B and Scheidereit C: Constitutive NF- $\kappa$ B maintains high expression of a characteristic gene network, including CD40, CD86, and a set of antiapoptotic genes in Hodgkin/Reed-Sternberg cells. Blood 97: 2798-2807, 2001 